\title{
PENGARUH INVESTASI FISIK DAN INVESTASI PEMBANGUNAN MANUSIA TERHADAP PERTUMBUHAN EKONOMI JAWA TIMUR 1990-2004
}

\author{
Achmad Sjafii \\ Fakultas Ekonomi Universitas Airlangga, Surabaya
}

\begin{abstract}
The roles of physical investment and government expenditure on economic development has been acknowledged in any various research. However, the study in the role of human capital investment on development economic just three decades later has been held. Human capital investment could be in the form of government expenditure, mainly to increase the quality of human resources. It consist of expenditure for the health and education. It is an importance factor to increase human development quality and enhance economic growth. The purposes of this research are to determine the influences of [1] private investment; [2] labor force growth; [3] government expenditure of East Java Province for human capital investment; [4] government expenditure of East Java Province for routine/annual expenditure; and [5] external condition on economic growth of East Java Province. The research applies panel data analysis, and it combines the cross section data in 37 regency/municipality and time series data for periods 1990-2004. The research applies the verification process that is the Hausman test. The verification test found that the suitable model is fixed effect (FE) model. It is found in this research that all the independent variables except "external condition" variable have statistically positive and significant influence on the economic growth in East Java Province.
\end{abstract}

Keywords: economic growth, physical investment and human capital investment.

\section{A. LATAR BELAKANG}

Investasi merupakan salah satu pilar pertumbuhan ekonomi. Investasi dapat berupa investasi modal fisik maupun investasi modal manusia. Investasi fisik (physical investment) yakni semua pengeluaran yang dapat menciptakan modal baru (Mankiw, 2000:24) atau meningkatkan stok barang modal. Sedangkan investasi sumber daya manusia (human capital investment) dapat berupa nilai-nilai pembelajaran dan pengalaman yang ada dalam diri tenaga kerja seperti peningkatan produktivitas dan pendapatan. ${ }^{2}$ Beberapa bentuk investasi sumber daya manusia dapat berupa pendidikan, kesehatan maupun migrasi (Schultz, 1961).

Peranan investasi fisik dalam memacu pertumbuhan ekonomi sudah tidak perlu diragukan lagi. Sementara itu pendidikan dan kesehatan merupakan faktor penting dalam pembangunan manusia sekaligus merupakan penentu dari indeks pembangunan manusia (IPM). Hal ini mengingat pendidikan dan kesehatan akan berdampak pada kualitas modal manusia (human capital).

Dari berbagai studi telah dibuktikan bahwa modal manusia merupakan salah satu determinan penting dalam proses pertumbuhan ekonomi. Dengan kata lain antara pendidikan dan kesehatan dengan pertumbuhan ekonomi terdapat hubungan saling mempengaruhi (Ranis, 2004) dan (Andreosso dan Callaghan, 2000).

Pentingnya peranan modal manusia dalam pembangunan tampak pada perhatian dari berbagai pihak seperti pemerintah maupun swasta yang mengalokasi investasi maupun belanja daerahnya 


\section{Journal of Indonesian Applied Economics \\ Vol. 3 No. 1 Mei 2009, 59-76}

guna meningkatkan kualitas modal manusia tersebut. Memang, investasi yang dialokasikan untuk kepentingan modal manusia ini tidak serta merta dapat dilihat hasilnya dalam jangka waktu singkat. Sehingga tidaklah heran bahwa di dalam anggaran pemerintah sering kali terjadi tarik-menarik antara investasi untuk infrastruktur ekonomi (fisik) dan investasi untuk sektor pembangunan modal manusia.

Di satu sisi pengeluaran investasi infrastruktur dibutuhkan untuk memfasilitasi pertumbuhan ekonomi, namun di sini lain diperlukan juga investasi untuk meningkatkan kualitas sumber daya manusia. Meningkatnya perbaikan modal manusia sebetulnya juga memberikan manfaat positif bagi pertumbuhan ekonomi melalui tersedianya tenaga kerja yang berkualitas.

Pentingnya modal manusia dalam proses pembangunan di negara berkembang telah dibuktikan banyak studi (Todaro, 2003:405). Namun ironis, di beberapa negara berkembang, tingginya pendapatan rumah tangga tidak selalu menjamin tingginya tingkat kesehatan. Karenanya modal manusia harus tetap mendapatkan perhatian tersendiri, bahkan di dalam perekonomian yang tumbuh dengan cepat sekalipun. Namun perlu diperhatikan, peningkatan kualitas modal manusia dapat membantu keluarga untuk keluar dari jebakan lingkaran setan kemiskinan.

Disini, mutlak diperlukan investasi swasta maupun pengeluaran pemerintah sektor publik untuk pembangunan manusia baik di pemerintah pusat maupun pemerintah daerah lokal. Selama ini pengeluaran pembangunan pemerintah lokal masih terkonsentrasi pada bidang infrastruktur ekonomi dan belum memberikan perhatian yang memadai bagi bidang pembangunan manusia. Karenanya peneliti ingin melakukan studi sejauh mana pengaruh investasi modal manusia khususnya dan investasi fisik umumnya dari pemerintah kabupaten/kota maupun swasta terhadap pertumbuhan ekonomi di Jawa Timur. Lebih lanjut, penelitian ini bertujuan untuk mengetahui pengaruh investasi swasta, pertumbuhan tenaga kerja, investasi modal manusia pemerintah kabupaten/ kota di Jawa Timur, konsumsi pemerintah kabupaten/kota di Jawa Timur, krisis ekonomi (kondisi eksternal) terhadap pertumbuhan ekonomi Jawa Timur.

\section{B. KAJIAN TEORITIS}

\section{Teori Pertumbuhan R. Solow}

Menurut Robert Solow (Solow neoclassical growth model) bahwa faktor-faktor yang mempengaruhi pertumbuhan ekonomi diantaranya adalah stok modal, pertumbuhan tenaga kerja, dan perkembangan teknologi. Model Pertumbuhan Solow ini merupakan pengembangan dari formulasi Harrod-Domar dengan menambahkan variabel tenaga kerja, serta memperkenalkan faktor teknologi. Model Harrod-Domar mengasumsikan skala hasil tetap (constant return to scale) dengan koefisien baku, dimana model tersebut menunjukkan hubungan antara investasi dan pertumbuhan ekonomi (Todaro, 2003:150). Investasi (netto) adalah penambahan stok barang modal, sehingga dapat ditulis:

$$
\begin{aligned}
I_{t} & =\Delta K \\
& =K_{t}-K_{t-1}
\end{aligned}
$$

Adapun ICOR (incremental capital output ratio) adalah kebalikan dari rasio pertumbuhan output terhadap pertumbuhan investasi, yang pada intinya menunjukkan hubungan antara penambahan stok barang modal dan pertumbuhan output. Hal ini untuk melihat seberapa besar peningkatan investasi yang diperlukan untuk mendapatakan laju pertumbuhan ekonomi tertentu yang telah ditentukan sebelumnya, sehingga dapat ditulis:

$$
\begin{array}{ll}
Y & =y K \\
1 / y & =K / Y
\end{array}
$$

dimana $y=$ rasio ouput-kapital; dan $1 / y=$ rasio kapital-output (COR). Dengan demikian ICOR dapat ditulis: 


$$
\text { ICOR }=\frac{\Delta K / Y}{\Delta Y / Y} \quad \text { atau } \quad \text { ICOR }=\frac{\Delta K}{\Delta Y}
$$

Model pertumbuhan Solow menun-jukkan bagaimana pertumbuhan dalam stok modal, pertumbuhan tenaga kerja, dan perkembangan teknologi mempengaruhi tingkat output. Apabila dimisalkan suatu proses pertumbuhan ekonomi dalam kondisi teknologi belum berkembang, maka tingkat pertumbuhan yang telah dicapai hanya karena perubahan jumlah modal $(\boldsymbol{K})$ dan jumlah tenaga kerja $(\boldsymbol{L})$ dan hubungan kedua faktor faktor tersebut, sehingga dapat ditulis:

$$
Y=f(K, L)
$$

dimana $Y$ adalah pendapatan nasional (output). Dalam kenyataannya teknologi sulit dipisahkan dalam proses pembangunan, sehingga perubahan teknologi turut dimasukkan ke dalam fungsi produksi, maka dapat ditulis:

$$
Y=A f(K, L)(5)
$$

dimana A adalah tingkat teknologi pada saat sekarang atau disebut sebagai total factor productivity (TFP). Oleh karenanya, output meningkat bukan hanya karena peningkatan modal dan tenaga kerja semata-mata, tetapi juga disebabkan oleh kenaikan TFP. Dengan memasukkan TFP, maka persamaan (4) dapat ditulis:

dimana $\Delta A / A$ adalah pertumbuhan IHP (Solow residual: Mankiw, 1997:120).

TFP dapat berubah dengan beberapa alasan, antara lain adanya peningkatan pengetahuan pada metode produksi. Solow residual dapat digunakan untuk mengukur perkembangan teknologi. Faktorfaktor produksi seperti pendidikan dan regulasi pemerintah dapat mempengaruhi TFP. Misalkan, jika pengeluaran pemerintah meningkat, hal ini dapat meningkatkan kualitas pendidikan sehingga pekerja menjadi lebih produktif dan ouput akan meningkat. Pada akhirnya TFP menjadi lebih besar (Mankiw, 1997).

Sementara itu Mankiw, Romer, dan Weil dalam Berg (2001) telah menguji model Solow yang telah diperluas (augmented Solow model) dengan menambahkan "modal manusia" terhadap fungsi produksi. Baik Mankiw, Romer, dan Weil menunjukkan bahwa modal fisik maupun modal manusia per pekerja akan meningkat selama besarnya investasi mencu-kupi untuk mengimbangi kebutuhan tenaga kerja baru, menutup depresiasi, maupun kelebihan tenaga kerja akibat kemajuan teknologi. Pada dasarnya perekonomian selalu membutuhkan penggantian modal manusia yang telah terdepresiasi.

\section{Teori Pertumbuhan Endogen (Penekanan Modal Manusia)}

Teori ini lebih menekankan peran kualitas modal manusia. Pemikiran tentang modal manusia ini mula-mula dikembangkan oleh Uzawa (1965) dan digunakan oleh Lucas (1988). Bila menggunakakan fungsi produksi Cobb-Douglas dengan constant return terhadap modal fisik (K) dan modal manusia $(\mathrm{H})$, maka dapat ditulis:

$$
Y=A K^{\alpha} H^{(1-\alpha)}
$$

dimana $0 £$ a $£ 1$. $H$ adalah modal manusia yang merupakan jumlah tenaga kerja $L$ dikalikan dengan sejumlah tenaga kerja tertentu $h$. Spesifikasi ini memberikan arti bahwa jumlah tenaga kerja $L$ yang tidak berubah tidak akan menjadi sumber dari diminishing terurn.

Asumsi bahwa total tenaga kerja $L$ adalah tetap dan $H$ berkembang karena perbaikan rata-rata kualitas $h$. Asumsi berikutnya adalah bahwa tidak terjadi kemajuan teknologi. Stok modal fisik dan modal manusia terdepresiasi pada tingkat yang sama sebesar $d$. Modal manusia terdepresiasi karena penurunan kemampuan dan kematian. Perubahan stok modal dapat ditulis:

$$
\dot{K}=I_{K}-\delta K
$$




$$
\dot{H}=I_{H}-\delta H
$$

Sehingga marginal product of phisical capital dapat ditulis:

$$
d Y / d K=A \alpha K^{\alpha}[H / K]^{(1-\alpha)}
$$

sedangkan marginal product of human capital dapat ditulis:

$$
d Y / d H=A(1-\alpha) K^{\alpha}[H / K]^{-\alpha}
$$

Untuk mengoptimalkan penggunaan kedua faktor produksi tersebut maka, rasio stok modal manusia terhadap modal fisik dapat ditulis:

$$
H / K=\frac{(1-\alpha)}{\alpha}
$$

Dengan melakukan substitusi aljabar diperoleh bentuk akhir dari model dasar Uzawa-Lucas sebagai berikut:

$$
Y=A K[(1-\alpha) / \alpha]^{(1-\alpha)}
$$

Ternyata untuk menghasilkan model $A K$ dimana besarnya output ditentukan oleh kontribusi modal fisik (a), makin kecil kontribusi modal fisik (a) atau makin besar kontribusi modal manusia (1-a) dalam fungsi produksi makin tinggi output yang dihasilkan (Baroo dan Martin, 1995:172174).

\section{Pengeluaran Pemerintah dan Pertumbuhan Ekonomi}

Pengaruh pengeluaran pemerintah terhadap pertumbuhan ekonomi merupakan salah satu fenomena penting dalam perekonomian. Kegiatan pemerintah secara langsung maupun tidak langsung memung-kinkan terjadi peningkatan output melalui interaksi dengan sektor swasta (privat). Menurut Lin (1994) tingkat pertumbuhan yang tinggi dapat dicapai melalui pengeluaran pemerintah pada tingkat yang tinggi pula.

Pengaruh pengeluaran publik terhadap pertumbuhan ekonomi bergantung pada jenis pengeluarannya. Pengeluaran pemerintah untuk investasi dan kegiatan produktif lainnya dapat berpengaruh secara positif terhadap pertumbuhan ekonomi. Namun dalam beberapa hal pengeluaran pemerintah justru meng-hambat pertumbuhan ekonomi (Barro, 1990).

Menurut Harrod-Domar, berbagai macam pengeluaran pemerintah akan berdampak positif pada pertumbuhan ekonomi. Aspek utama yang dikembangkan pada teori ini adalah peranan investasi yang berdampak positif melalui proses pengganda (multiplier effect) terhadap permintaan agregat maupun penawaran agregat melalui pengaruh dalam kapasitas produksi.

\section{Peranan Pendidikan dan Kesehatan Dalam Pembangunan Ekonomi}

Kesehatan merupakan prasyarat bagi peningkatan produktivitas. Kesehatan dan pendidikan dapat dilihat sebagai komponen pertumbuhan dan pembangunan yang vital dan merupakan input fungsi produksi agregat. Peran gandanya sebagai input maupun output menyebabkan kesehatan dan pendidikan sangat penting dalam pembangunan ekonomi (Todaro, 2003:404).

Berdasarkan pengalaman di beberapa negara, Psacharopoulus (1972) dalam Todaro (2000) membuktikan bahwa pendidikan memang memiliki pengaruh yang positif terhadap promosi pertumbuhan ekonomi. Peningkatan kesehatan, pendidikan dan nutrisi bukan hanya mampu meningkatkan kapabilitas saja, namun juga merupakan sarana penting dalam meningkatkan "modal manusia" di masa yang akan datang. Peningkatan pendidikan secara umum dapat pula memperbesar poduktivitas dan kemampuan untuk meningkatkan pendapatan (perekonomian) yang lebih tinggi baik pada saat ini maupun masa yang akan datang. 


\section{Pengaruh Investasi Fisik dan Investasi Pembangunan Manusia}

Disamping itu perbaikan di bidang pendidikan dan kesehatan akan berdampak pada capaian pembangunan manusia. Hal ini mengingat indikator dalam indeks pembangunan manusia (IPM) oleh UNDP menempatkan pendidikan dan kesehatan sebagai indikator utama disamping indikator ekonomi. Pendek kata pembangunan manusia telah memberikan sumbangan terbesar bagi pencapaian keberlangsungan pembangunan (Anand dan Sen, 2000: 2038).

Pembangunan manusia tidak menge-sampingkan pertumbuhan ekonomi. Bahkan boleh dikatakan terdapat hubungan, meskipun secara tidak langsung antara peningkatan pendapatan dan kemajuan pembangunan manusia itu sendiri. Peranan pengeluaran pembangunan oleh pemerintah (APBN) turut berperan dalam peningkatan pembangunan manusia (BPS-BappenasUNDP, 2004:71)

\section{Pembangunan Manusia}

Terminologi pembangunan manusia dalam Indonesia Human Development Report (2001:10) adalah proses dimana masyarakat dimungkinkan untuk dapat memperluas ber-bagai pilihanpilihan. Pendapatan merupakan salah satu dari sekian pilihan, tetapi bukanlah seluruh kebutuhan hidup. Kesehatan dan pendidikan, lingkungan yang baik serta kebebasan dalam bertindak jauh lebih penting. Hal ini juga dikuatkan dalam Indonesia Human Development Report (2004:70) bahwa pembangunan manusia sangat berkepentingan dengan kapabilitas manusia termasuk di dalamnya adalah peningkatan dalam kesehatan dan pendidikan.

Kesehatan dan pendidikan bukan hanya sekedar input fungsi produksi namun juga merupakan tujuan pembangunan yang fundamental. Peningkatan kesehatan dan pendidikan dapat membantu masyarakat untuk keluar dari jebakan lingkaran setan kemiskinan. Sekelompok orang yang berpendidikan akan dapat memberi manfaat kepada masyarakat di sekelilingnya, seperti menciptakan berbagai inovasi yang berguna bagi komunitasnya (Todaro, 2003:413).

Pembangunan manusia didasarkan pada tiga tujuan akhir pembangunan: masa hidup (longevity) diukur dengan usia harapan hidup, pengetahuan (knowledge) yang diukur dengan kemampuan baca tulis orang dewasa secara tertimbang dan rata-rata tahun bersekolah, serta standar kehidupan (standard of living) yang diukur dengan pendapatan riil per kapita, disesuaikan dengan paritas daya beli (purchasing power parity atau PPP) untuk mencerminkan biaya hidup (Todaro,2003: $68)$.

\section{Studi Theodore W. Schultz}

Studi tentang investasi sumber daya manusia telah dilakukan oleh Schultz sekitar tahun 1960an. Schultz berpendapat bahwa investasi sumber daya manusia akan mampu meningkatkan kualitas sumber daya itu menjadi lebih produktif dan merupakan salah satu cara untuk keluar dari perbudakan. Meningkatnya sumber daya manusia ini akan menjadikan manusia memiliki lebih banyak pilihan sehingga akan tercipta peningkatan kesejahteraan.

Beberapa kegiatan yang menurut Schultz (1961:8) dapat memperbaiki kemampuan sumber daya manusia adalah pendidikan formal yang paling memiliki hubungan erat dengan peningkatan kemampuan sumber daya manusia.

\section{Pertumbuhan Ekonomi dan Pembangunan Manusia}

Studi Lee Jong Hwa tentang hubungan antara pertumbuhan ekonomi dan pem-bangunan manusia di Republik Korea periode (1945-2002), telah memberikan gambaran bahwa antara kedua indikator tersebut memiliki kaitan yang cukup erat. Artinya pertumbuhan ekonomi akan menjadikan pembangunan manusia semakin baik, begitu pula sebaliknya akibat dari perbaikan kualitas manusia tersebut dalam jangka panjang akan menjadikan kinerja perekonomian akan meningkat.

Ranis (2004) menyatakan bahwa pembangunan manusia merupakan dampak dari pengembangan modal manusia. Sedangkan perbaikan dari modal manusia itu sendiri tidak terlepas dari perbaikan 


\section{Journal of Indonesian Applied Economics \\ Vol. 3 No. 1 Mei 2009, 59-76}

kinerja ekonomi. Dengan kata lain antara kinerja ekonomi dan dampaknya terhadap pembangunan manusia maupun sebaliknya merupakan kaitan yang cukup kuat.

Kaitan antara pertumbuhan ekonomi dan pembangunan manusia dapat dipilah menjadi 2 jalur oleh Ramirez, et al (1998). Jalur pertama, kinerja ekonomi mempengaruhi pembangunan manusia, khususnya melalui aktivitas rumah tangga dan pemerintah, selain adanya peran sipil seperti melalui organisasi masyarakat dan lembaga swadaya masyarakat.

Jalur kedua, dari pembangunan manusia ke pertumbuhan ekonomi. Tingkat pemba-ngunan manusia yang tinggi akan mempengaruhi perekonomian melalui pening-katan kapabilitas penduduk dan konsekuen-sinya adalah juga pada produktivitas dan kreativitas mereka. Pendidikan dan kesehatan penduduk sangat menentukan kemampuan untuk menyerap dan mengelola sumbersumber pertumbuhan ekonomi baik dalam kaitannya dengan teknologi sampai kelemba-gaan yang penting bagi pertumbuhan ekonomi.

Hasil studi Yuji Kubo dan Yong Sun Lee (1995) terhadap 78 negara maju dan negara berkembang menunjukkan bahwa baik investasi fisik maupun investasi modal manusia mempunyai hubungan yang positif terhadap pertumbuhan pendapatan perkapita.

\section{Studi Pengeluaran Pemerintah Untuk Pendidikan dan Kesehatan}

Filmer dan Pritchett (1997) menemukan bahwa 95 persen variasi tingkat kematian anak dapat dijelaskan oleh non-health policy yaitu faktor-faktor antara lain: pendapatan per kapita, distribusi pendapatan, tingkat pendidikan wanita, dan faktor budaya. Sementara dampak pengeluaran pemerintah yang diukur menggunakan alokasi anggaran, sangat kecil dan secara statistik tidak signifikan.

Penelitian Reinenikka dan Ablo (2003) tentang dampak pengeluaran pemerintah pada bidang kesehatan dan pendidikan di negara-negara Afrika menunjukkan bahwa (1) membaiknya kondisi sosial ekonomi, yang diperkuat dengan semakin meningkatnya kontribusi nyata pemerintah terhadap gaji guru, telah meningkatkan angka partisipasi sekokah dasar sebesar 60 persen dalam kurun waktu 1991-1995

Gupta, Verhoeven dan Tiongson (1999) menggunakan data cross section 50 negara sedang berkembang menunjukkan adanya hubungan positip antara pengeluran kesehatan minimal dengan tingkat kematian balita. Studi sebelumnya yang dilakukan oleh Bidani dan Ravallion (1997) menunjukkan adanya hubungan positip antara pengeluaran kesehatan masayarakat dengan tingkat harapan hidup dan kematian balita.

Rajkumar dan Swaroop (2002) dalam studinya menitikberatkan pada peranan pengeluaran pemerintah dan outcome sektor pendidikan dan kesehatan menunjukkan (1) pengeluaran pemerintah di sektor kesehatan menurunkan tingkat kematian balita pada negara-negara dengan good governance. (2) sejalan dengan perbaikan-perbaikan menuju good governance, pengeluaran pemerintah pada sektor pendidikan dasar menjadi efektif dalam meningkatkan hasil proses pendidikan dasar.

Ranis, Stewart, dan Ramirez (2000: 208), menyatakan bahwa pengeluaran pemerintah berdampak positif terhadap perbaikan di bidang pendidikan dan kesehatan khususnya untuk kaum perempuan. Dalam arti yang lebih luas, perbaikan di bidang pendidikan dan kesehatan akan menguatkan pembangunan manusia yang pada akhirnya akan mendukung pertumbuhan ekonomi.

\section{Studi Tentang Peranan Pemerintah Lokal Terhadap Pertumbuhan Ekonomi Daerah}

Studi yang dilakukan oleh Kim (1997) tentang peranan sektor publik lokal terhadap pertumbuhan ekonomi regional di Korea tahun 1990-1991 menunjukkan hasil yang signifikan. Investasi dan konsumsi daerah berpengaruh positif terhadap pertumbuhan ekonomi daerah. Model Kim diturunkan dari model pertumbuhan regional dengan $\boldsymbol{n}$ sektor dalam suatu wilayah. Sehingga kondisi ini dapat ditulis: 


$$
Y=\sum_{i=1}^{n} P_{i} Q_{i}
$$

dimana

$P_{i}$ : harga dari barang yang diproduksi di sektor $i$,

$Q_{i}:$ kuantitas yang diproduksi di sektor $i$.

Nilai tambah masing-masing sektor dipengaruhi oleh investasi pemerintah dalam dalam infrastruktur serta pengeluaran pemerintah daerah untuk jasa-jasa tertentu. Dengan demikian, output untuk masing-masing sektor merupakan fungsi dari aktivitas pemerintah ditambah input swasta yang berupa modal dan tenaga kerja, ditulis:

$$
Q_{i}=\left(K_{i}, L_{i}, K_{g}, G\right)(15)
$$

dimana $i=1,2, \ldots, n$. Oleh Kim (1997:161) persamaan (15) dijabarkan:

$$
\left.\stackrel{*}{Y}=\beta_{0}+\beta_{k}\left[\frac{I_{p}}{Y}\right]+\bar{\beta}_{i}{ }^{*}+\gamma_{\chi}\left[\frac{I_{g}}{Y}\right]+\gamma_{g}\left(\left[\frac{G}{Y}\right]^{*}\right)+\phi \frac{R_{e}}{Y}\right]
$$

$K_{i}$ dan $L_{i}$ merupakan modal dan tenaga kerja swasta di sektor $i$; $K_{\mathrm{g}}$ mengukur besarnya modal pemerintah daerah; dan $G$ merupakan konsumsi pemerintah. Variabel $G$ dimasukkan dalam semua sektor yang memungkinkan memperluas pengaruh aktivitas pemerintah daerah. Sebagai tambahan, pengaruh modal pemerintah dapat tercermin dari barang publik lokal untuk masing-masing fungsi produksi dan mungkin berbeda dari modal swasta.

Ikhsan dan Basri (1991) menunjukkan bahwa hasil secara signifikan pengeluaran investasi pemerintah berpengaruh terhadap perubahan investasi swasta. Perlu diketahui, kedua hubungan tersebut bersifat komple-menter daripada substitusi. Artinya, aktivitas pada sektor pemerintah mendapat respon positif dari sektor swasta.

Penelitian lain yang menggunakan data panel dilakukan oleh Solihin (2002); Afiatno dan Tohari (2005). Pada penelitian itu dikaji perananan sektor publik terhadap pertumbuhan 37 daerah di Jawa Timur.

Hasil penelitian tersebut menyebutkan bahwa secara signifikan pengeluaran investasi yang dilakukan oleh pemerintah lokal mempunyai dampak positif terhadap pertumbuhan masing-masing daerah.

\section{Studi Pembangunan Manusia dan Pengurangan Kemiskinan}

Keterkaitan antara pengeluaran peme-rintah pada peningkatan pembangunan manusia dan berpengaruh terhadap penurunan tingkat kemiskinan telah diakui oleh Ranis dan Stewart (2000). Studi sejenis tentang dampak pengeluaran pemerintah pada pertumbuhan ekonomi, atau dampak pengeluaran pemerintah pada status kesehatan dan hasil proses pendidikan.

Brata (2005) mengambil data panel untuk 31 propinsi di Indonesia dalam periode 1996-2002. Telah terungkap bahwa investasi sektor publik dalam bidang pembangunan manusia sangat diperlukan untuk meningkatkan kualitas sumber daya manusia serta dapat menekan tingkat kemiskinan.

Hasil penelitian oleh Lanjouw, et al. (2001) mengungkapkan bahwa pembangunan manusia sangatlah penting dalam upaya mengurangi tingkat kemiskinan. Hal ini karena investasi dibidang pendidikan dan kesehatan yang baik memungkinkan penduduk miskin untuk meningkatkan nilai asetnya. Sehubungan dengan itulah maka investasi pada pendidikan dan kesehatan sangat penting artinya bagi pengurangan kemiskinan. 


\section{Journal of Indonesian Applied Economics}

Vol. 3 No. 1 Mei 2009, 59-76

\section{Kerangka Konsep Penelitian}

Tujuan pembangunan yang telah sekian lama mendewa-dewakan target pertumbuhan ekonomi yang didapatkan dari investasi fisik perlu diimbangi dengan investasi non-fisik. Disini perlunya masyarakat pada umumnya maupun pemerintah khususnya menaruh perhatian terhadap investasi dibidang sumber daya manusia (human capital) dalam bidang kesehatan dan pendidikan. Hal ini mengingat kesehatan dan pendidikan berkaitan erat dengan pembangunan ekonomi. Oleh karena adanya hubungan diantara variabel-variabel tersebut, maka kebijakan pembangunan diupayakan lebih memusatkan perhatian pada peningkatan pendapatan, kesehatan, dan pendidikan secara bersama-sama.

Atas dasar kenyataan di atas, maka pengeluaran pemerintah yang diperuntukkan bagi kesehatan dan pendidikan baik lokal maupun pusat hendaknya lebih ditekankan guna untuk meningkatkan indikator pembangu-nan manusia. Hal ini mengingat tingkat kesejahteraan tidaklah semata-mata ditentukan dari investasi fisik semata-mata. Namun pengeluaran untuk kesehatan dan pendidikan selayaknya perlu diseimbangkan juga. Dari uraian di atas dapatlah dibuat kerangka pikir seperti tampak pada Gambar 1 di bawah ini. Atas dasar penjelasan dan kerangka pikir tersebut, maka hipotesis untuk penelitian ini adalah Diduga investasi swasta, pertumbuhan tenaga kerja, investasi modal manusia pemerintah kabupaten/kota di Jawa Timur, konsumsi pemerintah kabupaten/kota di Jawa Timur, dan kondisi eksternal yakni krisis ekonomi berpengaruh secara signifikan terhadap pertumbuhan ekonomi di Jawa Timur.

\section{METODE PENELITIAN}

\section{Pendekatan Penelitian}

Penelitian ini menggunakan pendekatan kualitatif dan kuantitatif. Berikutnya teknik analisis penelitian ini melibatkan interpretasi dengan menggunakan pendekatan kuantitatif dan pendekatan kualitatif (penalaran kritis).

\section{Tempat dan Waktu Penelitian}

Penelitian ini menggunakan data panel yang merupakan gabungan antara data kerat lintang (cross section) yang terdiri dari 29 kabupaten dan 8 kota, tidak termasuk Kota Batu yang masih dianggap sebagai bagian dari Kabupaten Malang ( $\mathrm{i}=37$ ) serta data runtut waktu (time series) periode 1990-2004 atau 15 observasi $(\mathrm{t}=15)$.

\section{Jenis dan sumber data}

Data yang dipergunakan adalah data sekunder yang diperolah dari BPS Jawa Timur; Badan Perencanaan Pembangunan Provinsi (Bappeprov) Jawa Timur; dan Anggaran Pengeluaran dan Belanja Daerah (APBD) masing-masing kabupaten/kota. Unit analisis penelitian ini untuk seluruh variabel (independen dan dependen) adalah kabupaten/kota di Jawa Timur.

\section{Definisi dan Pengukuran Variabel}

$\dot{Y}$ menunjukkan pertumbuhan ekonomi (variabel dependen) diperoleh dari pertumbuhan PDRB atas dasar harga konstan tahun 2000 diukur dengan cara $\left[\left(\mathrm{PDRB}_{\mathrm{t}}-\mathrm{PDRB}_{\mathrm{t}-1}\right) / \mathrm{PDRB}_{\mathrm{t}-1}\right] \mathrm{x}$ 100. Pertumbuhan eko-nomi di provinsi Jawa Timur terbagi atas tiga bagian, yakni:

- Periode 1990-1997, merupakan periode pertumbuhan ekonomi yang relatif stabil. Pada periode ini lebih tinggi daripada rata-rata pertumbuhan ekonomi nasional.

- Periode 1998-1999, merupakan periode terpuruknya pertumbuhan ekonomi hingga mencapai angka minus pada semua kabupaten/kota. Keadaan ini lebih dikenal dengan periode krisis ekonomi. 
- Periode 2000-2004, merupakan masa pemulihan ekonomi (recovery) dimana pada periode tersebut pertumbuhan ekonomi bergerak naik secara perlahan.

$I_{p}$ (variabel independen) adalah investasi swasta, merupakan pengeluaran sektor swasta yang ditujukan untuk meningkatkan stok barang modal (capital stock), kemudian dikonstankan dengan tahun dasar 2000 melalui deflator PDRB. Nilai investasi swasta dalam harga konstan dirasiokan terhadap PDRB harga konstan tahun 2000 dikalikan 100, ditulis $\left[\frac{I_{p}}{Y}\right]$.

$I_{\text {he }}$ (variabel independen) adalah investasi pemerintah bidang kesehatan dan bidang pendidikan kabupaten/ kota yang diperoleh dari realisasi pengeluaran APBD kabupaten dan kota di Jawa Timur, kemudian dikonstankan atas tahun dasar 2000 (melalui deflator PDRB) dan dirasiokan terhadap PDRB harga konstan tahun 2000 dikalikan 100, ditulis $\left[\frac{I_{h e}}{Y}\right]$. Variabel $\dot{I}_{g}$ menunjukkan pertumbuhan investasi pemerintah kabupaten/ kota dalam harga konstan tahun 2000. Hasilnya dikalikan dengan rasio investasi SDM pemerintah terhadap PDRB $\left(\frac{I_{h e}}{Y}\right)$, ditulis $\left[\left(\frac{I_{h e}}{Y}\right) \dot{I}_{g}\right]$.

Variabel $\dot{L}$ (variabel independen) adalah pertumbuhan tenaga kerja yang diukur dengan $\operatorname{cara}\left[\left(\mathrm{L}_{\mathrm{t}}-\mathrm{L}_{\mathrm{t}-1}\right) / \mathrm{L}_{\mathrm{t}-1}\right] \times 100$.

Variabel $G$ (variabel independen) adalah konsumsi pemerintah kabupaten/kota diperoleh dari realisasi pengeluaran APBD (provinsi-kabupaten/ kota) untuk belanja rutin, lalu dikonstankan atas tahun dasar 2000 (melalui deflator PDRB). Selanjutnya nilai konsumsi tersebut dirasiokan

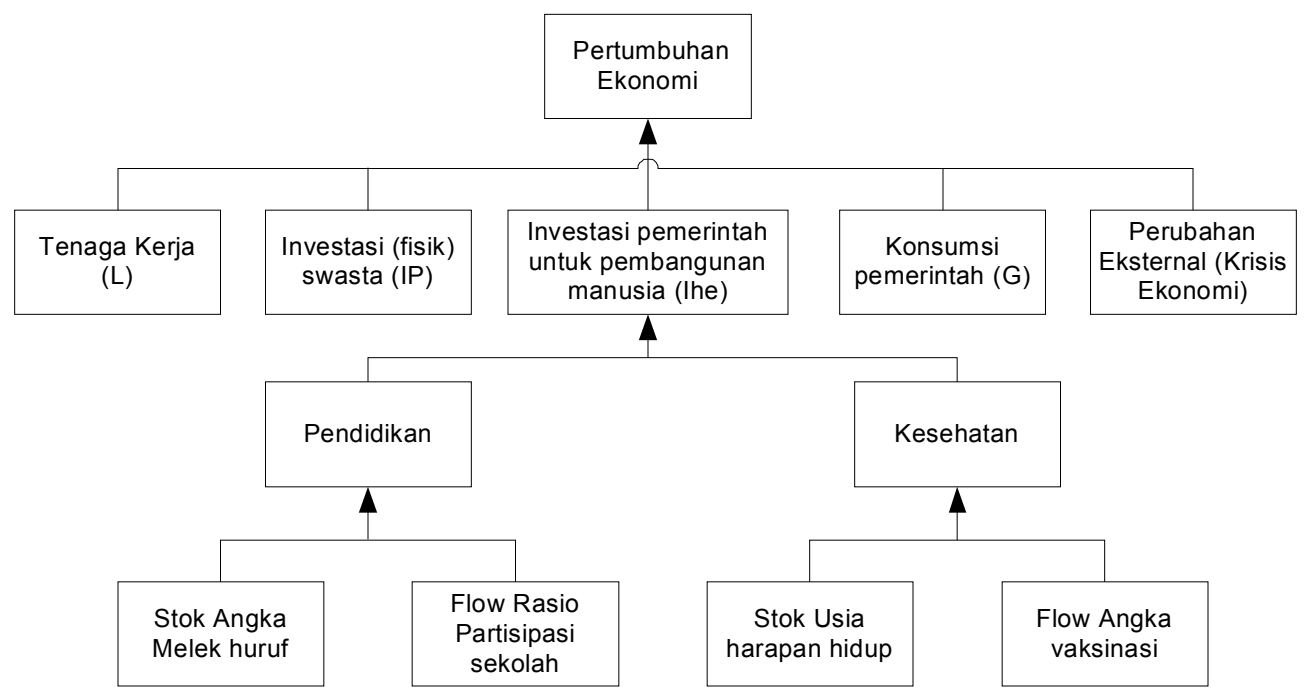

Gambar 1. Kerangka Pikir "Hubungan Pertumbuhan Ekonomi dengan Investasi Fisik dan Investasi Modal Manusia" 
terhadap PDRB dalam harga konstan tahun 2000 dikalikan 100, ditulis $\left(\frac{G}{Y}\right)$. Variabel $\dot{G}$ menunjukkan pertumbuhan konsumsi pemerintah dalam harga konstan tahun 2000 yang diukur dengan cara $\left[\mathrm{G}_{t}-\mathrm{G}_{t-1}\right] / \mathrm{G}_{t-1} \times 100$. Hasilnya dikalikan dengan rasio konsumsi pemerintah erhadap $\operatorname{PDRB}\left(\frac{G}{Y}\right)$, ditulis $\left[\left(\frac{G}{Y}\right) \dot{G}\right]$.

Variabel boneka $D$ (dummy variable) untuk keadaan krisis ekonomi $(1998-1999)=1$ dan bukan krisis ekonomi $=0$. Selengkapnya model yang akan diestimasi dapat ditulis sebagai berikut:

$$
\dot{Y}_{i t}=\beta_{i i}+\beta_{k t}\left(\frac{I_{p}}{Y}\right)_{i t}+\beta_{i i}^{\dot{L}} \dot{L}_{i t}+\gamma_{s t}\left[\left(\frac{I_{h e}}{Y}\right) \dot{I}_{g}\right]_{i t}+\gamma_{g t}\left[\left(\frac{G}{Y}\right) \dot{G}_{G}\right]_{i t}+\phi_{i} D_{i t}+\mu_{t t}
$$

\section{Teknik Analisis dan Pengolahan Data}

Teknik analisis dan pengolahan data menggunakan regresi linier berganda (multiple linear regression) yang diterapkan untuk data panel (gabungan antara data kerat lintang dan data runtut waktu).

Berdasarkan penelitian yang pernah dikembangkan oleh Kim (1997) oleh peneliti dijadikan sebagai landasan dalam merancang model untuk melihat pertumbuhan perekonomian kabupaten/ kota di Jawa Timur yang dipengaruhi oleh input swasta maupun aktivitas pemerintah. Aktivitas pemerintah tampak dari pengeluaran untuk modal fisik maupun pengeluaran sektor publik lainnya diantaranya adalah investasi pemerintah pada bidang kesehatan dan pendidikan.

\section{Model Regresi Linier Berganda dengan Data Panel}

Metode estimasi yang akan digunakan adalah general least square (GLS). Metode GLS adalah transformasi dari metode OLS (ordinary least square) dengan satu per akar varians (standard error) atau 1/s [Gujarati, 2003]. Penggunaan metode estimasi GLS adalah untuk mengatasi gangguan heterokedastisitas yang cenderung terjadi pada jenis kerat lintang.

\section{Uji Hausman}

Dalam memilih model fixed effects $(\mathrm{FE})$ atau random effects $(R E)$ untuk memperoleh estimator yang baik, maka digunakan hipotesis sebagai berikut:

Hipotesis dalam uji Hausman yaitu:

$H_{0}$ : terpilih RE (random effects)

$H_{1}$ : terpilih FE (fixed effects)

\section{HASIL DAN PEMBAHASAN}

\section{Dinamika Pertumbuhan Ekonomi Jawa Timur 1990-2004}

Laju pertumbuhan ekonomi merupakan indikator ekonomi makro yang sangat strategis. Boleh dikatakan berhasil tidaknya program-program pembangunan dinilai berdasarkan tinggi rendahnya pertumbuhan ekonominya (Todaro, 2000: 136).

Pada periode sebelum krisis pertumbuhan ekonomi relatif stabil tinggi untuk seluruh kabupaten/ kota di Jawa Timur yakni rata-rata sebesar 6,12 persen. Angka pertumbuhan tertinggi dicapai oleh Kota Malang yakni 14,44 persen (1990) dan Kabupaten Sidoarjo setinggi 14,05 persen (1991). Angka pertumbuhan terendah dicapai oleh Kota Mojokerto 3,54 persen dan Kabupaten Tuban setinggi 0,83 persen . 


\section{Pengaruh Investasi Fisik dan Investasi Pembangunan Manusia}

Pertumbuhan ekonomi tersebut tidak terlepas dari sumbangan investasi sektor swasta. Peranan investasi swasta terhadap pertumbuhan ekonomi Jawa Timur rata-rata sebesar 23,15 persen. Pertumbuhan tenaga kerja turut berpengaruh terhadap kinerja pertumbuhan ekonomi Jawa Timur. Pertumbuhan tenaga kerja tumbuh rata-rata hampir sebesar 1,69 persen, dengan pertumbuhan tertinggi di Surabaya sebesar 6,49 persen (1996) dan pertumbuhan terendah terdapat di Kabupaten Sumenep sebesar 0,18 persen (1997).

Sementara itu, peranan investasi modal manusia yang dilakukan oleh pemerintah lokal terhadap PDRB kabupaten/kota selama periode tersebut rata-rata sebesar 2,47 persen. Namun hal tersebut berbeda dengan konsumsi pemerintah lokal $(\mathrm{G})$ atau pengeluaran rutin pemerintah lokal. Variabel tersebut berdampak langsung terhadap pertumbuhan PDRB sebesar 39,86 persen. Keadaan ini menunjukkan bahwa peranan konsumsi pemerintah lokal terhadap perkembangan PDRB di Jawa Timur 16 kali lebih besar dibandingkan pengeluaran untuk investasi SDM.

Pada periode kedua keadaan perekonomian Jawa Timur khususnya maupun Indonesia pada umumnya tengah mengalami krisis ekonomi. Di Jawa Timur kondisi ini ditandai oleh beberapa indikator sosial ekonomi yang menunjukkan kinerja yang menurun dibandingkan periode sebelumnya. Diantaranya adalah pertumbuhan ekonomi selama periode ini mencapai minus $(16,29$ persen) tahun 1998 dan 1,04 persen pada tahun 1999.

Keadaan ini merupakan akibat dari berbagai aktivitas baik sektor pemerintah maupun swasta yang mengalami kelesuan, diantaranya adalah pertumbuhan peranan investasi swasta merosot dibandingkan periode sebelumnya yakni menjadi 22,07 persen. Demikian dengan pertumbuhan tenaga kerja yang terlibat dalam perekonomian turut mengalami penurunan hingga menjadi minus (3,22 persen) pada tahun 1998. Hal ini dimungkinkan karena saat itu banyak sektor swasta yang mengalami kebangkrutan sehingga tidak sedikit tenaga kerja yang kehilangan pekerjaan atau status mereka menjadi pengangguran.

Pada saat yang sama pertumbuhan investasi modal manusia yang dilakukan oleh pemerintah dalam periode tersebut juga mengalami penurunan hingga mencapai minus $(8,05$ persen $)$ pada tahun1998. Keadaan ini menjadikan IPM Jawa Timur pada tahun 1999 menduduki peringkat ke22 dari 26 propinsi di Indonesia saat itu (BPS-Bappenas-UNDP, 2001:78).

Dalam periode ini, pertumbuhan dan peranannya konsumsi pemerintah lokal terhadap PDRB mengalami peningkatan yang cukup berarti dibandingkan periode sebelumnya yakni menjadi ratarata sebesar 85,82 persen. Peningkatan yang cukup berarti ini mengindikasikan bahwa peranan pengeluaran pemerintah dalam masa krisis ekonomi demikian dominan. Hal ini bisa dimengerti mengingat pengeluaran/investasi swasta saat itu menurun cukup berarti.

Pada periode setelah krisis keadaan perekonomian Jawa Timur pada umumnya tengah mengalami periode recovery. Keadaan ini ditandai dengan semakin membaiknya beberapa indikator sosial ekonomi diban-dingkan periode sebelumnya, diantaranya adalah kecenderungan pertumbuhan ekonomi dari 3,28 persen pada tahun 2000 hingga 5,28 persen pada tahun 2004. Secara umum pertumbuhan PDRB kabupaten/kota di Jawa Timur mengalami peningkatan rata-rata sebesar 3,70 persen.

Sementara itu peringkat IPM Jawa Timur mengalami peningkatan dari 61,8 pada tahun 1999 (krisis ekonomi) menjadi 64,1 tahun 2002 (BPS-Bappenas-UNDP, 2004:97). Bahkan pada tahun 2004 IPM Jawa Timur telah meningkat lagi menjadi 64,49 (Pemerintah Provinsi Jawa Timur dan BPS, Indikator Makro Sosial - Ekonomi Jawa Timur 2004: 279).

Pada periode tersebut dapat dikatakan hampir semua variabel penelitian telah meningkat dengan cukup pesat. Pertumbuhan tenaga kerja yang ada dalam perekonomian turut mengalami peningkatan dari 1,97 persen pada tahun 2000 hingga mencapai 3,12 persen pada tahun 2004. Secara umum pertumbuhan tenaga kerja kabupaten/kota di Jawa Timur mengalami peningkatan rata-rata sebesar 2,61 persen. Namun demikian pertumbuhan peranan investasi swasta terhadap PDRB pada periode setelah krisis justru tidak mengalami kenaikan seperti halnya variabel penelitian lainnya.

Peranan investasi pembangunan manusia oleh pemerintah lokal terhadap PDRB selama periode pemulihan juga mengalami peningka-tan rata-rata hingga 15,65 persen. Sebagai akibat dari keadaan 
tersebut, maka dapat dilihat bahwasannya IPM Jawa Timur pada periode ini juga mengalami peningkatan dari 61,8 pada tahun 1999 (krisis ekonomi) menjadi 64,1 tahun 2002 dan bahkan meningkat lagi menjadi 64,49 pada tahun 2004.

Dalam periode ini, pertumbuhan peranan konsumsi pemerintah lokal terhadap PDRB mengalami peningkatan yang cukup berarti dibandingkan periode sebelumnya yakni menjadi rata-rata sebesar 292,02 persen. Peningkatan yang cukup berarti ini mengindi-kasikan bahwa perkembangan perekonomian daerah masih sangat menggantungkan peranan pengeluaran pemerintah. Hal ini mengingat bahwa pengeluaran pemerintah lokal masih memiliki generating effect yang cukup kuat terhadap perekonomian lokal.

Dari penjelasan di atas dapat dikatakan bahwa keadaan pertumbuhan ekonomi yang semakin meningkat akan membawa pengaruh positif bagi membaiknya kualitas manusia atau meningkatnya IPM. Kondisi tersebut seperti yang terjadi pada periode setelah krisis ekonomi (2000-2004).

Sedangkan pertumbuhan ekonomi yang kontraktif atau mengarah negatif cenderung sebaliknya, yakni selain berdampak negatif pada kualitas manusia (periode 1998-1999) juga dapat menurunkan kualitas manusia yang tercermin dari semakin meningkatnya indeks kemiskinan manusia IKM.

Dengan demikian peningkatan kualitas sumber daya manusia (tercermin dari kenaikan IPM) suatu wilayah memerlukan peningkatan pertumbuhan ekonomi yang memadai. Bila IPM membaik hal ini akan mengikis kemiskinan masyarakat itu sendiri (tercermin dari penurunan IKM).

\section{Dinamika Investasi Fisik, Investasi Pembangunan Manusia dan Kemiskinan}

Perkembangan peranan investasi fisik yang dilakukan oleh pihak swasta terhadap PDRB Jawa Timur terus mengalami penurunan. Penurunan tersebut berlangsung buka hanya terjadi selama periode krisis ekonomi berlangsung, namun setelah periode krisis pun keadaan ini tetap berlangsung (Gambar 2). Peranan investasi swasta terhadap pertumbuhan ekonomi Jawa Timur sebelum memasuki periode krisis berkisar rata-rata sebesar 23,15 persen. Dalam periode krisis, investasi swasta merosot dibandingkan periode sebelumnya yakni menjadi 22,07 persen

Pertumbuhan peranan investasi swasta tetap cenderung turun rata-rata hingga mencapai 15,04 persen meskipun pertumbuhan ekonomi cenderung meningkat. Penurunan ini diduga erat kaitannya dengan kondisi non-ekonomi sendiri, diantaranya adalah (a) country risk dan penegakan hukum yang lemah, (b) muatan bahan impor yang belum ada substitusi, (c) birokrasi (pungli), (d) tumpang tindih dalam per-UU-an dan Perda, (e) unjuk rasa buruh yang berdampak pada stabilitas produksi terganggu.(www.kompas.com/kompas cetak/0301/10/jatim/77519.htm)

Hal tersebut memberikan sinyal bahwa pertumbuhan ekonomi yang semakin membaik belum tentu akan diimbangi dengan minat investor untuk menanamkan investasinya di wilayah tersebut bila tidak diimbangi dengan situasi yang kondusif pada bidang lainnya. Dengan kata lain, investor memerlukan investment incentive baik beruna faktor ekonomi maupun di luar faktor ekonomi.

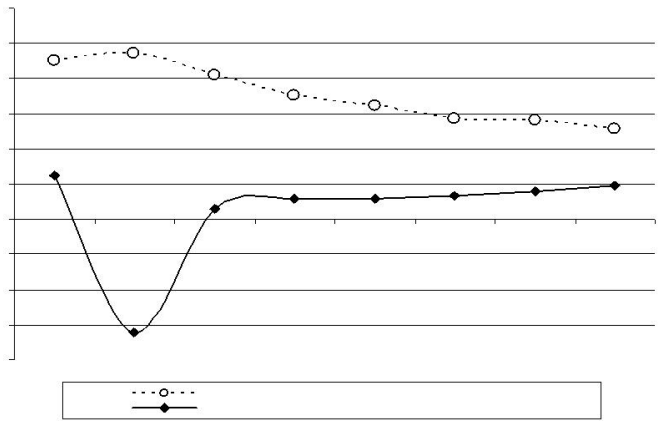

Gambar 2. Peranan Investasi Swasta Terhadap PDRB (\%) Pada Kabupaten/Kota di Jawa Timur 1990-2004 
Sementara itu investasi untuk pembangunan manusia oleh pemerintah lokal mengalami pasang surut. Jenis investasi ini merupakan pengeluaran pemerintah di luar belanja rutin yang ditujukan untuk meningkatkan kinerja di bidang kesehatan dan pendidikan masyarakat. Pengeluaran ini diharapkan dapat meningkatkan berbagai indikator pendidikan dan kesehatan dalam rangka memperkuat kualitas modal manusia.

Peningkatan kualitas modal manusia ini bisa tampak dari pencapaian tingkat pendidikan tertinggi (education attainment) dan usia harapan hidup (life expectancy). Pada gilirannya modal manusia yang berkualitas akan dapat meningkatkan produktivitas penduduk atau tenaga kerja maupun promosi bagi pertumbuhan ekonomi.

Pada Tabel 1 tampak bahwa dampak pengeluaran pemerintah bidang pendidikan dan kesehatan tersebut berpengaruh positif terhadap pembangunan manusia dan pertumbuhan ekonomi serta penurunan tingkat kemiskinan, melalaui peningkatan status kesehatan dan hasil proses pendidikan.

Tabel 1Perkembangan Pengeluaran Pemerintah Untuk Pembangunan Manusia Terhadap PDRB, IPM dan IKM Kabupaten/Kota di Provinsi Jawa

\begin{tabular}{|c|c|c|c|c|c|c|}
\hline \multirow{2}{*}{$\begin{array}{l}\text { Rata- } \\
\text { rata } \\
\text { Wilayah }\end{array}$} & \multirow{2}{*}{\multicolumn{2}{|c|}{$\begin{array}{c}\text { Proporsi Pemb } \\
M \text { an usia dr } \\
\text { APB D :PDR B* }\end{array}$}} & \multicolumn{2}{|c|}{ IP M ** } & \multicolumn{2}{|c|}{ IK M ** } \\
\hline & & & 1999 & 2004 & 1996 & 2004 \\
\hline $\mathbf{K} \mathbf{a} \mathbf{b}$ & 0,48 & 0,55 & 63,61 & 64,36 & 27,22 & 24,32 \\
\hline Kota & 0,36 & 0,64 & 67,60 & 70,88 & 16,79 & 16,06 \\
\hline Jatim & 0,25 & 0,29 & 61,80 & 64,49 & 23,50 & 21,70 \\
\hline \multicolumn{7}{|c|}{ Sumber: ${ }^{*} A P B D k a b u p a t e n / k o t a d i J a w a T$ T $u r,{ }^{* *} U N D P$} \\
\hline
\end{tabular}

Sementara itu pengeluaran pemerintah untuk pendidikan akan berdampak pada perbaikan taraf kesehatan. Peningkatan taraf kesehatan terlihat dari penurunan indikator angka kematian bayi (infant mortality rate) dari 48 tahun 1999 menjadi 39 tahun 2004. Adapun peningkatan status kesehatan masyarakat dapat terlihat kenaikan angka harapan hidup (life expectancy). Pada periode yang sama terjadi peningkatan angka harapan hidup penduduk Jawa Timur dari 65,48 tahun pada 1999 menjadi 67,20 tahun pada 2004 (UNDP-BPS-Bappenas, 2001:30). Lihat Gambar 3.

Di lain pihak indikator IPM Jawa Timur mengalami pasang surut seiring dengan kondisi perekonomian yang terjadi. Pada masa krisis ekonomi, IPM mengalami penurunan dari tahun $1996(65,5)$ dibandingkan IPM pada tahun $1999(61,8)$. Akibat krisis tersebut telah terjadi kontraksi sebesar 5,65 persen. Kontraksi tersebut terjadi di seluruh kabupaten/ kota, di mana kontraksi tertinggi terjadi di Kabupaten Situbondo yaitu 7,43 persen sedangkan kontraksi terendah terjadi di Kabupaten Sampang sebesar 1,87 persen.

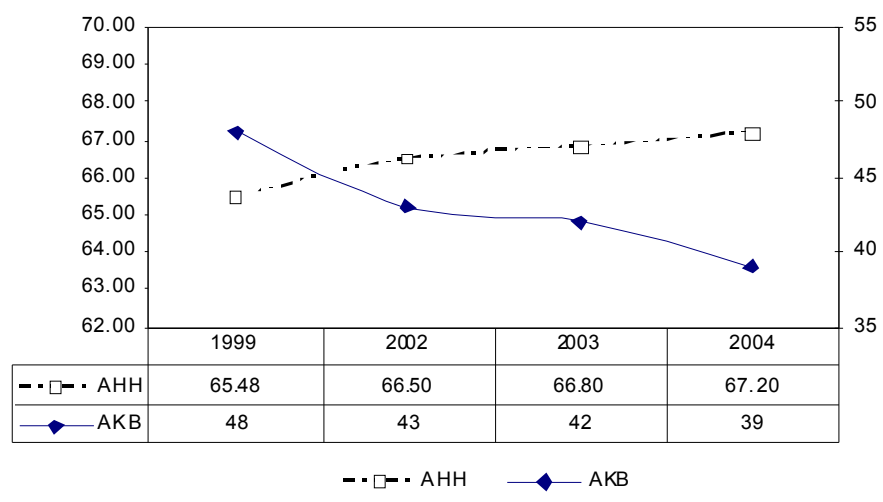

Gambar 3. Hubungan Penurunan Angka Kematian Bayi (AKB) dan Angka Harapan Hidup (AHH) Penduduk Jawa Timur Periode 1999-2004 


\section{Journal of Indonesian Applied Economics \\ Vol. 3 No. 1 Mei 2009, 59-76}

IPM Jawa Timur tahun 2002 dapat dikatakan sedikit meningkat dibandingkan tahun 1999. IPM Jawa Timur untuk tahun 2002 sebesar 62,64 dibandingkan 61,80 untuk tahun 1999 sehingga dapat dikatakan terjadi peningkatan sebesar 1,36 persen. Sebenarnya, sebagian besar kabupaten/ kota cenderung telah pulih kondisi perekonomianya yang dicerminkan oleh peningkatan pembangunan manusianya. Namun, peningkatan tersebut belum dapat diikuti oleh beberapa daerah lainya di mana besaran IPM-nya untuk tahun 2002 mengalami kontraksi dibandingkan tahun 1999 yaitu Kabupaten Bondowoso, Kota Malang dan Kabupaten Pacitan.

\section{Interpretasi Model Pertumbuhan Ekonomi Jawa Timur}

Melalui berbagai verifikasi hingga uji Hausman maka ditetapkan model fixed effects (FE).

Variabel bebas dalam model yang terdiri dari Investasi swasta $\left(I_{p}\right)$, tenaga kerja $(L)$, pengeluaran/ investasi pemerintah lokal untuk bidang kesehatan dan pendidikan $\left(I_{h e}\right)$, pengeluaran konsumsi pemerintah $(G)$, dan faktor eksternal/variabel dummy $(D)$ memiliki koefisien yang secara statistik signifikan mempengaruhi pertumbuhan ekonomi Jawa Timur. Seluruh variabel tersebut berpengaruh positif terhadap pertumbuhan ekonomi, kecuali variabel eksternal berpengaruh negatif.

Pengaruh setiap kenaikan 1 persen variabel bebas, diantaranya tenaga kerja terhadap pertumbuhan ekonomi di Jawa Timur adalah sebesar 0,71 persen. Kenaikan investasi swasta berpengaruh terhadap pertumbuhan ekonomi Jawa Timur sebesar 0,29 persen. Adapun peningkatan pengeluaran pemerintah untuk bidang pembangunan manusia berpengaruh terhadap pertumbuhan ekonomi sebesar 0,02 persen. Sedangkan peningkatan terhadap konsumsi pemerintah lokal berdampak terhadap pertumbuhan ekonomi sebesar 0,0014 persen.

Hasil analisis koefisien baku menunjukkan bahwa urutan variabel bebas yang paling berpengaruh terhadap pertumbuhan ekonomi di Jawa Timur adalah faktor eksternal yakni krisis ekonomi $(D)$, disusul oleh pertumbuhan tenaga kerja $(L)$, investasi swasta $\left(I_{p}\right)$, pengeluaran/ investasi pemerintah lokal untuk bidang kesehatan dan pendidikan , dan pengeluaran konsumsi pemerintah yang berpengaruh terhadap perekonomian di Jawa Timur.

\section{Keterbatasan Penelitian}

1. Pemisahan data investasi swasta untuk pendidikan dan kesehatan maupun di luar pendidikan dan kesehatan untuk tingkat kabupaten/kota. Data tersebut hanya dapat ditemukan pada tingkat nasional.

2. Data untuk investasi swasta itu sendiri untuk tingkat kabupaten/kota sulit didapatkan. Hal ini mengingat data investasi swasta yang terealisasi bukanlah data investasi swasta total yang sesungguhnya terjadi.

3. Perubahan pengeluaran pemerintah dalam APBD dari tahun fiskal menjadi tahun kalender menggunakan metode interpolasi, sebenarnya bisa dicari dari laporan realisasi 3 bulanan pada masing-masing instansi di kabupaten/ kota.

4. Pengeluaran pemerintah untuk sektor kesehatan dan pendidikan dapat muncul pada sisi "pengeluaran rutin" maupun "pengeluaran pembangunan" terutama setalah adanya Keputusan Menteri Dalam Negeri (Kepmendagri) No. 29 Tahun 2002". Sebelum Kepmendagri tersebut, yang dimaksudkan hanya pengeluaran pemerintah untuk sektor kesehatan dan sektor pendidikan yang terdapat dalam pengeluaran pembangunan saja.

5. Tidak semua kabupaten/ kota memisahkan pengeluaran pemerintah untuk pembangu-nan manusia yakni untuk sektor kesehatan dan sektor pendidikan secara rinci. Terdapat beberapa kabupaten /kota yang cara pengelompokannya berbeda-beda, meskipun untuk maksud yang sama. 


\section{Pengaruh Investasi Fisik dan Investasi Pembangunan Manusia}

6. Data ketenagakerjaan di tiap kabupaten/ kota didapatkan dari instansi yang berbeda-beda sehingga berpotensi memunculkan angka yang berbeda pula.

\section{E. KESIMPULAN DAN REKOMENDASI}

\section{Kesimpulan}

1. Seluruh variabel bebas dalam penelitian berpengaruh secara signifikan terhadap variabel terikat yakni pertumbuhan ekonomi Jawa Timur. Peningkatan inves-tasi swasta, pertumbuhan tenaga kerja, pengeluaran pemerintah untuk bidang pembangunan manusia, maupun konsumsi pemerintah lokal mempunyai peranan dalam meningkatkan pertumbuhan ekonomi Jawa Timur. Adapun perubahan eksternal pada makro ekonomi yakni krisis ekonomi akan berdampak terhadap penurunan pertumbuhan ekonomi.

2. Hasil analisis koefisien baku menunjukkan bahwa urutan variabel bebas yang paling berpengaruh terhadap pertumbuhan ekonomi di Jawa Timur adalah faktor eksternal yakni krisis ekonomi, disusul kemudian oleh pertumbuhan tenaga kerja, investasi swasta, pengeluaran/ investasi pemerintah lokal untuk bidang kesehatan dan pendidikan, dan pengeluaran konsumsi pemerintah yang berpengaruh terhadap perekonomian di Jawa Timur.

3. Investasi sektor publik untuk pemba-ngunan manusia yakni pengeluaran pemerintah bidang kesehatan dan pendidikan sangat diperlukan untuk meningkatkan kualitas sumberdaya manusia yang tampak dari Indeks Pembangunan Manusia. Pembangunan manusia itu sendiri akan dapat memacu pertumbuhan ekonomi lokal. Pada akhirnya pertumbuhan ekonomi tersebut dapat menekan indeks kemiskinan manusia (IKM).

\section{Rekomendasi}

1. Dalam rangka peningkatan kinerja pertumbuhan ekonomi Jawa Timur, diperlu adanya pembenahan diberbagai bidang diantaranya:

a. Perbaikan iklim investasi, karena dengan membaiknya iklim investasi swasta akan berperan mengurangi kemiskinan melalui penyediaan lapangan kerja yang memungkinkan terjadinya peningkatan pendapatan masyarakat. Persoalan iklim investasi bukan hanya masalah perizinan semata. Karenanya perbaikan iklim investasi memerlukan keterlibatan banyak pihak diantaranya adalah koordinasi antar departemen/ dinas terkait seperti pemerintah daerah (provinsi-kabupaten/kota), kantor pajak, kantor imigrasi, pejabat pelabuhan.

b. Strategi ketenagakerjaan. Secara mikro, kesempatan kerja dapat tercipta lebih banyak jika kebijakan investasi diarahkan pada usaha-usaha yang sifatnya padat karya (labor intensive) yang meliputi kegiatan pengembangan teknologi tepat guna dan program pembentukan kader wirausaha baik yang berpendidikan maupun non-pendidikan.

2. Program penciptaan kesempatan kerja hendaknya betul-betul memperhatikan jenis pekerjaan yang mampu dan layak dikerjakan oleh jenjang kompetensi mereka. Hal ini mengingat angkatan kerja didominasi merkea yang berpendidikan rendah (66,29 persen. Program terapan yang bersifat padat karya dengan memperhatikan sentuhan teknologi sederhana diyakini akan mampu berdampak pada sektor-sektor lainnya bahkan akan dapat menciptakan lapangan pekerjaan baru. 3. Diperlukan kemauan pemerintah untuk melaksanakan prioritas pengalokasian anggaran pada sektor pendidikan secara efisien. Tidak membedakan pembangu-nan fisik untuk sekolah negeri dan sekolah swasta dalam pembangunan fisik. Hal ini mengingat relatif banyaknya sekolah swasta dengan kualitas kurang baik dibandingkan sekolah negeri. Mekanis-menya dengan melalui perubahan komposisi pengeluaran rutin yang lebih ditekan sehemat mungkin dan memper-besar pengeluaran pembangunan khusus-nya pengeluaran yang langsung menam-bah manfaat sosial terutama yang berkaitan dengan pembangunan manusia yakni sektor kesehatan dan pendidikan. 


\section{Journal of Indonesian Applied Economics}

Vol. 3 No. 1 Mei 2009, 59-76

\section{Implikasi Kebijakan}

\section{Kebijakan Perbaikan Iklim Investasi}

a. Pendelegasian wewenang perizinan investasi dari pemerintah pusat kepada pemerintah daerah, dengan diikuti standar dan monitoring yang ketat, termasuk pemberian incentive dan disincentive pada pemerintah daerah.

b. Kegiatan promosi investasi hendaknya diimbangi dengan dengan perbaikan kondisi internal untuk mengimbangi persepsi negatif investor tentang inkonsistensi kebijakan pemerintah pada masa sebelumnya.

c. Khusus bagi Badan Koordinasi Penanaman Modal (BKPM) dan Pemerintah Provinsi Jawa Timur hendaknya menjadi leading institution sekaligus pengarah kebijakan penanaman modal bagi pemerintah kabupaten/kota agar segala peraturan daerah (Perda) tidak saling merugikan kepada investor.

\section{Kebijakan Kesempatan Kerja}

a. Disamping itu penyempurnaan sistem informasi ketenagakerjaan yang memungkinkan efektifnya monitoring, perencanaan kebutuhan tenaga kerja pada sektor-sektor tertentu khususnya pada sektor formal.

b. Investasi baru baik oleh swasta maupun pemerintah hendaknya betul-betul diarahkan pada pembukaan peluang kerja dengan prioritas menerima angkatan kerja yang berpendidikan menengah. Penciptaan lapangan yang berbasis hi-tech (capital intensive) hendaknya perlu dibatasi. Meskipun jenis pekerjaan tersebut dapat memperbesar output PDRB, namun dari sisi penciptaan lapangan kerja jumlahnya amat terbatas.

\section{Kebijakan Angggaran}

a. Perlu keseimbangan proporsi antara pengeluaran pembangunan untuk bidang pendidikankesehatan dengan pengeluaran untuk bidang-bidang lain seperti infrastruktur ekonomi. Pengelu-aran pemerintah yang bersifat seremonial yang berdampak langsung pada masyarakat hendaknya dikurangi. Hal ini perlu disertai dengan peningkatan efisiensi dalam pemanfaatannya.

b. Mengingat pengeluaran pemerintah berdampak positif terhadap perbaikan di bidang pendidikan dan kesehatan. Dalam arti lebih luas, perbaikan di bidang pendidikan dan kesehatan akan menguatkan pembangunan manusia yang pada akhirnya akan mendukung pertumbuhan ekonomi. Semakin besar pengeluaran akan berdampak pada peningkatan angka melek huruf dewasa yang pada gilirannya akan memperbaiki pembangunan manusia itu sendiri.

c. Mengingat pembangunan manusia penting bagi mengurangi tingkat kemiskinan sekaligus memutuskan lingkaran perangkap kemiskinan (the vicious circle of poverty), maka salah satu strategi untuk menekan angka kemiskinan dapat dilakukan melalui peningkatan kualitas manusia dengan memperkuat sektor kesehatan dan pendidikan. Sehubungan dengan itulah maka investasi pada pendidikan dan kesehatan sangat penting artinya bagi pengurangan kemiskinan.

\section{DAFTAR PUSTAKA}

Afiatno, Bambang E. 2005. Dekomposisi Pertumbuhan Ekonomi Regional Jawa Timur dari Pengaruh Pemerintah Daerah, Swasta, Fakultas Ekonomi. Tidak dipublikasikan. Surabaya.

Anand, S. and Ravallion, M. 1993. Human Development in Poor Countries: On the Role of Private Income and Public Service, The Juornal of Economic Perspectives, 7 (1): 133-150.

Anand, S. and Sen, A. 2000. Human Development and Economic Sustainabi-lity, World Develop- 


\section{Pengaruh Investasi Fisik dan Investasi Pembangunan Manusia}

Sjafii

ment 28 (12): 2029-2049.

Andreosso, Bernadette and O'Callaghan. 2002, Human Capital Accumulation and Economic Growth in Asia, National Europe Centre Paper 30.

Barro, R.J. 1990, Government Spending in a Simple Model of Endogenous Growth, Journal of Political Economy 98: S103 - S125.

Barro, R.J. and Martin, X.S.I. 1995. Economic Growth, International Edition, Mc Graw-Hill, New York.

Berg, Hendrik V.D. 2001. Economic Growth and Development, McGraw-Hill, New York.

Bidani, B. and Martin Ravallion. 1997. Decomposing Social Indicator Using Distributional Data”, Journal of Econometric 77: 125 - 139.

Easterly, W. and Rebelo, S. 1993. Fiscal Policy and Economic Growth, Journal of Monetary Economics 32: (3): $417-458$.

Filmer D. And Pritchett L. 1997, Child Mortality and Public Spending on Health: How Much Does Money Matter?, World Bank.

1999, "The Impact of Public Spending on Health: Does Money Matter?", Social Science and Medicine 49(1): 1309 - 1323.

Ghozali, Abbas. 2005. The Role of Education to Economic Growth. Intenational Seminar on "Towards A New Indonesia" University of Gadjah Mada for its $50^{\text {th }}$ Anniversary. Jogjakarta.

Kim, Sung Tai. 1997. The Role of Local Public Sectors in Regional Economic Growth ini Korea, Asian Economic Journal, 11: 155-168.

Kubo, Y dan Lee, YS. 1995. A Model of Endogenous Growth With A Trade-off Between Investment in Physical dan Human capital, Asian Economic Journal, 9 (22).

Lee, Jong-Wha. 2005. "Economic Growth and Human Development in The republic of Korea, 1945-1992. Occasional Paper No.24. www.hdr.undp.org/docs/publications/occational papers/ oc24aa. Pebruari, 6, 2006.

Loening, Ludger J. 2002. The Impact of Education on Economic Growth in Guatemala, Discussion Paper, Ibero-America Institute for Economic Research, Göttingen

Mankiw, N. Gregory, 2000, Teori Ekonomi Makro, Edisi Keempat, Penerbit Erlangga, Jakarta.

Pindyck, Robert S. dan Rubinfeld, Daniel L. 1998. Econometric Models and Economic Forecasts, Fourth Edition. McGraw-Hill, New York.

Perkins, et al. 2001. Economics of Development, Fifth Edition, W.W. Norton and Company, Inc., New York, hal. 206.

Rajkumar A.S. and Vinaya Swaroop. 2002, Public Spending and Outcomes: Does Governance Matter?, JEL: E62;O23, World Bank.

Ramirez, A., Raniz, G., and Stewart, F. 1998. Economic Growth and Human Capital, World Development 28 (2): 197-219 
Raniz, G., and Stewart, F. Strategy for Success in Human Development. http://hdr.undp.or./docs/ training/oxford/reading/Ranis\%20and\%20stewart.pdf 15 Pebruari 2005.

Reinikka R. and Ablo, E. 1998. "Do Budget Really Matter? Evidence from public spending on education and health in Uganda". Policy Research Paper 1926.

Schultz, Theodore W., 1961. Investment in Human Capital. American Economic Review, 36 (3): 12

Solihin, Achmad. 2002. Peranan Sektor Publik Lokal Terhadap Pertumbuhan Ekonomi Regional di Jawa Timur. Tesis. Program Pascasarjana Universitas Gadjah Mada. Tidak Dipublikasikan.

Todaro, MP. 2000. Economic Development. Seventh Edition. Addition Wesley. New York.

Todaro, MP. dan Smith, SC. 2003. Economic Development. Eighth Edition. Pearson Education Limited, United Kingdom. Haris Munandar dan Puji A.L. (Penterjemah). 2004. Pembangunan Ekonomi di Dunia Ketiga, Edisi Kedelapan. Penerbit Erlangga. Jakarta.

UNDP, BPS, dan Bappenas. 2001. Indonesia Human Development Report 2001. Towards a New concencus: Democracy and Human Development in Indonesia. Published Jointly by BPS - Statistics Indonesia, Bappenas and UNDP Indonesia.

UNDP, BPS, and Bappenas. 2004. Indonesia Human Development Report 2004, The Economics of Democracy: Financing Human Development in Indonesia. Published Jointly by BPS - Statistics Indonesia, Bappenas and UNDP Indonesia. 